\title{
Wound healing under the effect of iodine cadexomer in rats $^{1}$
}

\author{
Cicatrização de feridas sob efeito do cadexômero iodo em ratos
}

\author{
Ester Verônica Brustolin ${ }^{\mathrm{I}}$, Thelma Larocca Skare ${ }^{\mathrm{II}}$, Paulo Afonso Nunes Nassif ${ }^{\mathrm{II}}$, Maria de Lourdes Pessole Biondo-Simões ${ }^{\mathrm{III}}$, \\ Manoel Alberto Prestes ${ }^{\mathrm{I}}$, Laila Marim Ozono ${ }^{\mathrm{IV}}$, Camila Ercolin Ramos ${ }^{\mathrm{IV}}$ \\ IMaster in Surgery, FEPAR, Curitiba-PR, Brazil. Main author. Conception and design of the study, critical revision. \\ IIPhD in Surgery, Full Professor, FEPAR and Federal University of Parana (UFPR), Curitiba-PR, Brazil. Supervised all phases of the study, manuscript \\ writing and critical revision. \\ IIIPhD in Surgery, Associate Professor, UFPR, Curitiba-PR, Brazil. Intellectual and scientific content of the study. \\ ${ }^{\text {IV }}$ Graduate student, FEPAR, Curitiba-PR, Brazil. Involved with technical procedures.
}

\begin{abstract}
PURPOSE: To assess vthe action of iodine cadexomer in the healing process of surgical wounds in rats and if cytotoxicity occurs with the systemic absorption of iodine.

METHODS: Thirty six Wistar rats were used and performed 53 wounds with surgical punch of 6 mm diameter on them. Two lesions were made diametrically opposed on groups with distilled water (GAD) and sodium chloride (GCS); on the right lesions were used bandage with distilled water and on the left ones dressing with sodium chloride. In cadexomer iodine (GCI) group, a punch injury was made only on the left side and the dressing was carried out with cadexomer iodine. The groups were divided in two sub-groups according to the day of death (7 and 14). Microscopically was used H\&E staining, through which the inflammation could be observed and also the neovascularization. Staining with Masson trichrome studied fibrosis. TSH and free T4 were used for absorption recognition of iodine, and its toxic potential was performed before death with the animal anesthetized.

RESULTS: Microscopic analysis showed more marked intensity of inflammation in group GAD, subgroup 14 days. Neovascularization showed be discrete in GCS sub-group 14 days. Fibrosis was more pronounced in the group GCI. Comparing the types of treatment, there was statistical significance between groups GCI and GCS ( $<<0.013$ ). The TSH and T4, showed no difference between the control group and GCI in relation to the absorption of iodine. In evaluating the GCI and control groups, within each treatment, statistical significance was found between them $(\mathrm{p}<0.001)$ when compared the days of observation.
\end{abstract}

CONCLUSION: Cadexomer iodine had beneficial effects in all phases of the healing process without cytotoxicity due iodine absorption. Key words: Wound Healing. Iodine. Thyrotropin. Thyroxine. Rats.

\section{RESUMO}

OBJETIVO: Avaliar a ação do cadexômero iodo na cicatrização de feridas cirúrgicas em ratos e se ocorre citotoxicidade com a absorção sistêmica do iodo.

MÉTODOS: Utilizou-se 36 ratos Wistar nos quais realizaram-se 53 feridas cirúrgicas com punch de 6 mm de diâmetro. Foram confeccionados duas lesões diametralmente opostas nos animais dos grupos água destilada (GAD) e cloreto de sódio (GCS). Na lesão do lado direito foi utilizado curativo com água destilada e, na do esquerdo, curativo com cloreto de sódio. No grupo cadexômero iodo (GCI), foi feita apenas uma lesão com o punch no lado esquerdo e o curativo foi realizado com cadexômero iodo. Os grupos foram divididos em dois subgrupos conforme o dia da morte (7 e 14). Microscopicamente foi utilizada a coloração H\&E, através da qual foi observado o processo inflamatório e a neovascularização. Com a coloração tricômio de Masson foi estudada a fibrose. Para o reconhecimento da absorção do iodo e o seu potencial tóxico foi realizado, antes da morte com o animal anestesiado, dosagem do TSH e do T4 livre.

RESULTADOS: Na análise microscópica a intensidade da inflamação apresentou-se mais acentuada no grupo GAD, subgrupo 14 dias. $\mathrm{Na}$ análise da neovascularização ela apresentou-se discreta no GCS subgrupo 14 dias. Na avaliação da fibrose foi mais acentuada no 
grupo GCI. Na comparação nos tipos de tratamento houve significância estatística entre os grupos GCI e GCS (p<0,013). A dosagem do TSH e T4, não apresentou diferença entre o grupo controle e GCI em relação à absorção do iodo. Na avaliação dos grupos GCI e controle, dentro de cada tratamento, houve significância estatística entre eles $(\mathrm{p}<0,001)$, quando comparados os dias.

CONCLUSÃO: O cadexômero iodo apresentou efeito benéfico em todas as fases do processo cicatricial sem citotoxicidade pela absorção do iodo.

\section{Descritores: Cicatrização. Iodo. Tireotropina. Tiroxina. Ratos.}

\section{Introduction}

Wound healing consists in a coordinated interaction of cellular and molecular events to tissue rebuilt ${ }^{1}$. This event is a dynamic process that involves biochemical and physiological phenomena to ensure lesion restoration.

The factor that triggers the tissue healing is based on the type of damage. It can go to dermis, partially or completely, reaching the subcutaneous tissue or even neighbor involvement, defining the extent of the wound ${ }^{2}$. During the healing process the fibroblasts are the major cells in synthesis. When there is the formation of granulation tissue, proliferation moves into the wound, causing extracellular matrix production, connective tissue fibers and neovessels ${ }^{3}$.

Between 1840 and the World War II, the focus of wounds treatment and their healing process was based on the use of antiseptics and topical agents with antimicrobial protection and dry toppings. This time was the golden period of use of antiseptics, such as Dakin solution, Eusol, mercury and aluminum derivatives iodine $^{4}$.

Iodine was discovered in 1811. It is dark purple solid which dissolves in alcohol and potassium iodide. Initial iodine formulations promoted irritation, pain and skin discoloration; but the development of povidone-iodine and iodine cadexomer since 1949, demonstrated to be safer ${ }^{5}$. It is composed of dextrin and epichlorohydrin pearls that carry the iodine.

The thyroid is specialized in the synthesis of thyroxine (T4) and triiodothyronine (T3). It is practically the only tissue of the organism that is capable of capturing inorganic iodine and form organic compounds, passing into the blood as hormone T4 which contains four iodine molecules in its constitution. Thus, according to the World Health Organization (WHO), the adult organism needs to ingest about 150 micrograms of iodine daily to synthesize sufficient amounts of thyroid hormones ${ }^{7}$.

Currently there are several iodine presentations. The importance of studying these antiseptic solutions is to analyze whether cytotoxicity occurs with cadexomer iodine, if its concentration can inhibit or even harm the development of the regeneration process and if iodine absorption occurs.
This study aims to evaluate the results of the use of iodine cadexomer in second intention wound healing and to demonstrate if cytotoxicity occurs by absorption of iodine.

\section{Methods}

The study was approved by the Research Ethics Committee of Beneficent Evangelic Society of Curitiba.

The sample consisted of 36 adult male Wistar rats, aged 60 days and weighing $200 \mathrm{~g}$. In iodine cadexomer group (GCI), the entire length of lesion was covered with $0.5 \mathrm{ml}$ of cadexomer iodine gel and covered with a layer of dry gauze over the gel. In the sodium chloride group (GCS), after wound cleaning with distilled water, was placed $0.5 \mathrm{ml}$ of $0.9 \% \mathrm{NaCl}$ and dried with gauze coverage. In group of distilled water (GAD) the wound was only cleaned with distilled water and covered with dry gauze.

\section{Surgical procedure}

The animals were anesthetized with $80 \mathrm{mg} / \mathrm{kg}$ ketamine and $10 \mathrm{mg} / \mathrm{kg}$ xylazine intramuscularly in the right posterior thigh ${ }^{8}$. They were then placed in the prone position with front and rear members fixed on the wood support in order to not produce trauma.

Shaving was performed on area of $6 \mathrm{~cm}$ long $\mathrm{x} 4 \mathrm{~cm}$ wide, located in the thoracolumbar region, using as reference the spine and an imaginary line tangent to the insertion of the hind limbs; antisepsia with chlorhexidine alcohol and demarcation of the operative area with fenestrated sterile shield were sequentially done.

In the center trichotomized area was performed a surgical lesion with metallic punch with $6 \mathrm{~mm}$ in diameter resecting all tissue until the dorsal fascia (Figure 1).

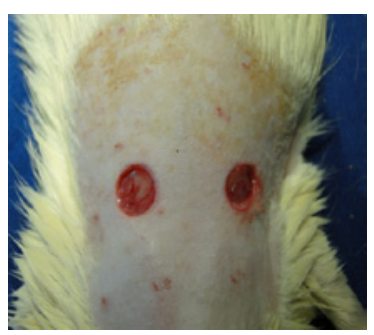

FIGURE 1 - Injuries made on the back position with a $6 \mathrm{~mm}$ punch device 
The animals were randomly distributed and established the therapy as mentioned for groups GCS, GAD and GCI. Each group was divided into subgroups of nine animals each, corresponding to the day of death, ie at seven and 14 days.

\section{Postoperative}

After the surgery, the animals received dipirone $10 \mathrm{mg} / \mathrm{kg}$ intramuscularly as analgesic medication. They were marked, kept in separate cages receiving water and balanced diet. The light-dark cycle was maintained artificially with periods of $12 \mathrm{~h}$.

The dressings were changed every three days, after sedation with diazepam $5 \mathrm{mg}$ to $15 \mathrm{mg} / \mathrm{kg}$, intramuscularly. The wounds were cleaned with sterile distilled water, leaving over them humid gauze to protect the lesion to be dried.

With the animals anesthetized, before death, $2 \mathrm{ml}$ blood sample was collected from cardiac puncture for TSH and free T4 measurements.

According to the day of death, each subgroup was killed with lethal intraperitoneal dose $(120 \mathrm{mg} / \mathrm{kg})$ of sodium thiopental.

Once death was held, a skin incision approximately $1.5 \mathrm{~cm}$ from the edges of the lesions was made using scalpel blade 20 (Figure 2). The samples were placed in solution of $10 \%$ formalin for histological analysis. H\&E staining was performed to assess inflammation, edema and neovascularization and Masson's trichrome for fibrosis.

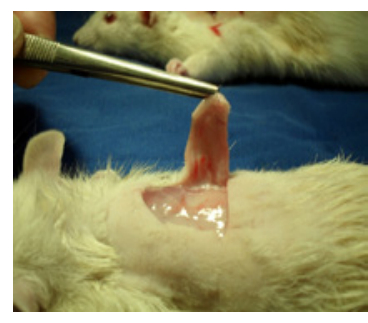

FIGURE 2 - Specimen for histological analysis.

\section{Statistical analysis}

Fisher exact test was used for independent groups and binomial for paired groups. Comparisons between groups of animals in relation to T4 and TSH were made considering the nonparametric Mann-Whitney test. $\mathrm{P}<0.05$ were considered statistically significant. Data were analyzed with Statistica v.8.0 program.

\section{Results}

Microscopic evaluation

The inflammation appeared more acute in the GAD $14^{\text {th }}$ day subgroup and more chronic in GCI group, subgroup 14 days (Figure 3). Regarding evaluation in days, two by two, within GAD and GCS treatment group no statistical significance $(\mathrm{p}>0.314)$ was reached when compared 7x14 days (Table 1).

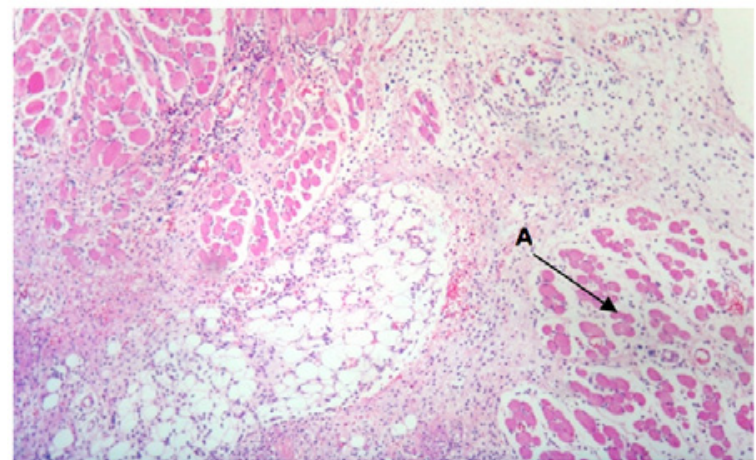

FIGURE 3 - Photomicrography showing acute and chronic inflammation (A).

TABLE 1 - Assessment of inflammation with HE

\begin{tabular}{|c|c|c|c|c|}
\hline staining & the & 7th & and & days \\
\hline $\begin{array}{c}\text { Inflammation } \\
\text { type }\end{array}$ & & GCI & GAD & GCS \\
\hline \multirow{2}{*}{ Acute } & 7 days & $55.56 \%$ & $66.67 \%$ & $88.89 \%$ \\
\hline & 14 days & $60.00 \%$ & $100.00 \%$ & $87.50 \%$ \\
\hline \multirow{2}{*}{ Chronicle } & 7 days & $44.44 \%$ & $33.33 \%$ & $11.11 \%$ \\
\hline & 14 days & $40.00 \%$ & $0.00 \%$ & $12.50 \%$ \\
\hline $\begin{array}{l}\text { Types of } \mathrm{t} \\
\text { reatment in } \\
\text { comparison }\end{array}$ & & GCI X GAD & GCI X GCS & GCS X GAD \\
\hline \multirow{2}{*}{ P value } & 7 days & 1 & 0.294 & 0.625 \\
\hline & 14 days & 0.103 & 0.314 & - \\
\hline
\end{tabular}

The intensity of the inflammation appeared more pronounced in the GCI group, subgroup 7th day (Table 2). In the days of evaluation, two by two in each treatment, GAD and GCS groups showed no statistically significant difference $(\mathrm{p}>0.05)$, compared 7x14 day (Table 2). 
TABLE 2 - Intensity of inflammation in mild, moderate and severe in $\mathrm{H} \& \mathrm{E}$ staining.

\begin{tabular}{ccccc}
\hline $\begin{array}{c}\text { Inflammation } \\
\text { type }\end{array}$ & & GCI & GAD & GCS \\
\hline $\begin{array}{c}\text { Slight or } \\
\text { moderate }\end{array}$ & 7 days & $33.33 \%$ & $44.44 \%$ & $55.56 \%$ \\
\hline & 7 days & $60.00 \%$ & $85.71 \%$ & $75.00 \%$ \\
\hline Accentuated & 7 days & $66.67 \%$ & $55.56 \%$ & $44.44 \%$ \\
\hline $\begin{array}{c}\text { Types of } \\
\text { treatment in } \\
\text { comparison }\end{array}$ & $40.00 \%$ & $14.29 \%$ & $25.00 \%$ \\
P value & 7 days & 1 & 0.637 & 1 \\
& 14 days & 0.338 & 0.638 & - \\
\cline { 2 - 5 } & & & &
\end{tabular}

Neovascularization appeared more pronounced in GCI group, subgroups 7 and 14 days. The analysis of this variable in relation to the days within each treatment, GAD and GCS groups were not statistically different when $7 \times 14$ days were compared (Table 3).

TABLE 3 - Intensity of neovascularization in mild, moderate and severe $-\mathrm{H} \& \mathrm{E}$ staining.

\begin{tabular}{ccccc}
\hline Neovascularization & & GCI & GAD & GCS \\
\hline \multirow{2}{*}{ Slight or moderate } & 7 days & $11.11 \%$ & $33.33 \%$ & $55.56 \%$ \\
& 14 days & $80.00 \%$ & $87.50 \%$ & $100.00 \%$ \\
\hline \multirow{2}{*}{ Accentuated } & 7 days & $88.89 \%$ & $66.67 \%$ & $44.44 \%$ \\
& 14 days & $20.00 \%$ & $12.50 \%$ & $0.00 \%$ \\
\hline $\begin{array}{c}\text { Types of treatment } \\
\text { in comparison }\end{array}$ & & GCI X PAD & GCI X GCS & GAD X GCS \\
P value & 7 days & 0.576 & 0.131 & 0.625 \\
\cline { 2 - 5 } & 14 days & 1 & 0.477 & - \\
\cline { 2 - 5 }
\end{tabular}

Fibrosis appeared stronger at the group GCI; comparison on the treatment types, there was statistical significance between groups GCI and GCS $(\mathrm{p}<0.013)$ (Figure 4 and Table 4$)$.

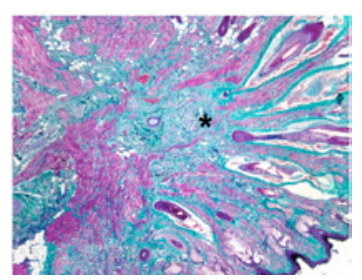

FIGURE 4 - Photomicrography of fibrosis by Masson trichrome staining $(*)$.
TABLE 4 - Analysis of fibrosis in Masson's trichrome staining

\begin{tabular}{ccccc}
\hline Fibrosis & & GCI & GAD & GCS \\
\hline Slight or & 7 days & $22.22 \%$ & $44.44 \%$ & $66.67 \%$ \\
moderate & 14 days & $40.00 \%$ & $62.50 \%$ & $100.00 \%$ \\
\hline \multirow{2}{*}{ Accentuated } & 7 days & $77.78 \%$ & $55.56 \%$ & $33.33 \%$ \\
& 14 days & $60.00 \%$ & $37.50 \%$ & $0.00 \%$ \\
\hline Types of & & GCI x GAD & GCI x GCS & GAD x GCS \\
treatment in & & & & \\
comparison & 7 days & 0.620 & 0.153 & 0.625 \\
P value & 14 days & 0.637 & 0.013 & 0.250 \\
\cline { 2 - 5 } & & & &
\end{tabular}

\section{Analysis of TSH and T4 in GCI and control groups}

Regarding the absorption of iodine, TSH and T4 showed no difference between the control group and in the evaluation of GCI on 7 and 14 days (Table 5).

Evaluation days on GCI and control groups, within each treatment, showed significant differences between them $(\mathrm{p}<0.001)$.

TABLE 5 - Values of T4 and TSH in the control and experimental groups.

\begin{tabular}{|c|c|c|c|c|c|c|c|c|c|}
\hline Variable & & Group & $\mathbf{n}$ & Average & Median & Minimum & Maximum & $\begin{array}{l}\text { Standard } \\
\text { deviation }\end{array}$ & P value \\
\hline \multirow{4}{*}{$\mathrm{T} 4$} & \multirow{2}{*}{7 days } & GCI & 9 & 1.43 & 1.49 & 0.92 & 1.89 & 0.36 & \\
\hline & & GAD / GCS & 9 & 1.55 & 1.51 & 1.17 & 1.90 & 0.25 & 0.546 \\
\hline & \multirow{2}{*}{14 days } & GCI & 9 & 1.29 & 1.14 & 0.85 & 1.75 & 0.37 & \\
\hline & & GAD / GCS & 7 & 1.23 & 1.15 & 0.87 & 1.80 & 0.34 & 1 \\
\hline \multirow{4}{*}{ TSH } & \multirow{2}{*}{7 days } & GCI & 9 & 1.14 & 0.88 & 0.45 & 2.86 & 0.77 & \\
\hline & & GAD / GCS & 9 & 1.36 & 1.22 & 0.81 & 2.86 & 0.60 & 0.094 \\
\hline & \multirow{2}{*}{14 days } & GCI & 9 & 0.44 & 0.40 & 0.39 & 0.71 & 0.10 & \\
\hline & & GAD / GCS & 7 & 0.61 & 0.50 & 0.40 & 0.88 & 0.23 & 0.055 \\
\hline
\end{tabular}

TSH values showed no significant changes between the GCI and control groups; they were statistically similar (Figure 5).

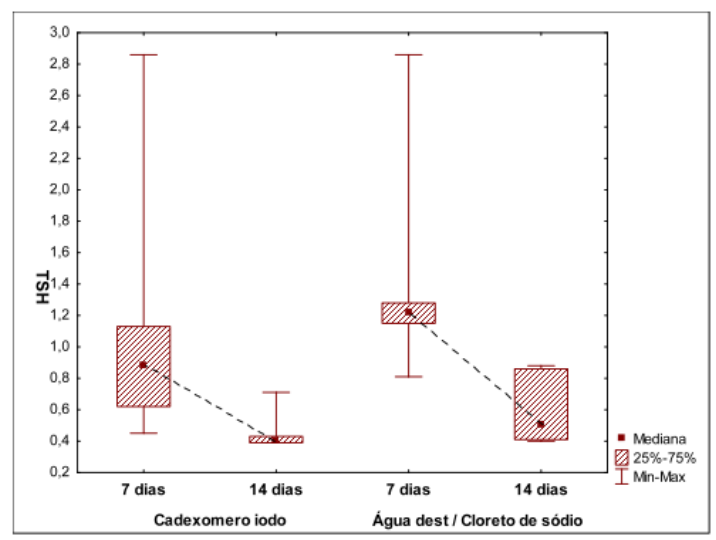

FIGURE 5 - Analysis of TSH between GCI and control groups. 


\section{Discussion}

It was decided to use the rat as animal model, due to the fact that it is more frequently observed in the literature on skin lesions. Additionally, contributes the fact that they are small animals, with easy acquisition, manipulation, standardization regarding weight, sex, age, housing, feeding, cleaning and care of experimental manipulation. Present low mortality, are resistant to infections and can be used in large numbers.

The $6 \mathrm{~mm}$ punch technique for performing the wounds was accurate and easy to standardize the lesions ${ }^{9}$.

This study used sodium chloride $0.9 \%$ for being isotonic solution containing $0.9 \% \mathrm{NaCl}$ in distilled water; this solution is widely used to perform cleaning of wound healing in skin. Distilled water was investigated in another group, because it is simple hydrolate containing no salt; is used in all types of wounds, including those with adjacent dermatitis.

It is known from literature that using saline, distilled or boiled water does not change the natural healing process in skin wounds ${ }^{10}$. This was observed in this study, where the saline solution and distilled water showed no interference at all stages of the healing process.

As Vogt et al. ${ }^{11}$ referred, healing in liquid and humid media is significantly faster when compared with dry wounds. Based on this concept, this study was developed in humid conditions with the aim to provide faster healing.

Histological evaluation used H\&E staining technique in order to observe the inflammatory process, edema and neovascularization. This staining is preferentially used on analysis of epithelial tissue ${ }^{12}$.

The inflammatory process is characterized by having hemostasis, provisional matrix deposition and cell migration. Angiogenesis is a fundamental step in the healing process, in which new blood vessels are formed from pre-existing ones. It begins with tissue injury, when macrophages are activated and their substances produced. The proteases (plasmin and collagenase) digest the base membrane and allow endothelial cells, stimulated by angiogenic cytokines, to form a new vascular ball that invades the wound, which is essential for the supply of oxygen and nutrients for healing process ${ }^{13}$.

The technique of Masson's trichrome was used to observe the formation of fibrosis, and was more pronounced in the group cadexomer iodine; these results are not similar to those found in the literature ${ }^{14}$.

Confirming of what Zhou et al. ${ }^{14}$ has published, in this study there was no cytotoxicity in fibroblast cells, when using the cadexomer iodine. It is noteworthy that this author, unlike this study, used this substance in vitro.

In this research, there were no negative effects of iodine cadexomer in relationship to the formation of granulation tissue, neovascularization and wound contraction. These results were similar to those of other authors ${ }^{15}$.showing that epidermal regeneration had positive effects throughout the healing process with its use. However, for the systemic absorption of iodine cadexomer, these results are contrary to other published ${ }^{16}$.

\section{Conclusion}

The iodine cadexomer had beneficial effects in all phases of the healing process without showing cytotoxicity for the absorption of iodine.

\section{References}

1. Ortonne JP, Clévy JP. Physiology of cutaneous cicatrization. Rev Prat. 1994;44(13):1733-7.

2. Mandelbaum SH, Di Santis EP, Mandelbaum MHS. Cicatrização: conceitos atuais e recursos auxiliares - Parte I. An Bras Dermatol. 2003;78(4):393-410.

3. Pagnano LO,Beraldi-Antoni SM, Pacheco MR, Santos E, Oliveira D, Lui JF. Morfometria de fibroblastos e fibrócitos durante o processo cicatricial na pele de coelhos da raça Nova Zelândia Branco tratados com calêndula. Cienc Rural. 2008;38(6):1662-6.

4. Sinclair RD, Ryan TJ. A great war for antiseptics. Australas J Dermatol. 1993;34(3):115-8.

5. Fa YH, Cai XW, Li ZR, Jin J, Wu F, Wang YH. Clinical study of repair the defect of immediate implant by acellular dermal matrix. Zhonghua Zheng Xing Wai Ke Za Zhi. 2006;22(2):123-6.

6. Szabolcs I, Szilágyi G, Góth M, Kovács Z, Weber M, Halász T. Plasma triiodothyronine response to thyrotropin releasing hormone, thyrotropin and propranolol in old age. Exp Gerontol. 1981;16(4):309-16.

7. WHO Secretariat, Andersson M, de Benoist B, Delange F, Zupan J. Prevention and control of iodine deficiency in pregnant and lactating women and in children less than 2-years-old: conclusions and recommendations of the Technical Consultation. Public Health Nutr. 2007;10(12A):1606-11.

8. Sharp PE, La Regina MC. The laboratory rat. Washington: CRC Press; 1998.

9. Carneiro MIS, Ribas-Filho JM, Malafaia O, Ribas CAPM, Santos CAM, Cavalcanti TCS, Czeczko LEA. Estudo comparativo do uso de extrato de pfaffia glomerata e do laser de baixa potência (hélioneônio) na cicatrização de feridas em ratos. ABCD Arq Bras Cir Dig. 2010;23(3):163-7.

10. Beam JW. Wound cleansing: water or saline? J Athl Train. 2006;41(2):196-7.

11. Vogt PM, Reimer K, Hauser J, Rossbach O, Steinau HU, Bosse B, Muller S, Schmidt T, Fleischer W. PVP-iodine in hydrosomes and hydrogel--a novel concept in wound therapy leads to enhanced epithelialization and reduced loss of skin grafts. Burns. 2006;32(6):698-705.

12. Sampaio CPP, Biondo-Simões MLP, Trindade LCT, Farias RE, Pierin RJ, Martins RC. Alterações inflamatórias provocadas pelo 
metronidazol em feridas: estudo experimental em ratos. J Vasc Bras. 2009;8(3):232-7.

13. Silva MM, Ribas-Filho JM, Malafaia O, Nassif PAN, Ribas MM, Varaschim M, Czeczko LE. A utilização da Pfaffia glomerata no processo de cicatrização de feridas da pele ABCD Arq Bras Cir Dig. 2010;23(4):228-33.

14. Zhou LH, Nahm WK, Badiavas E, Yufit T, Falanga V. Slow release iodine preparation and wound healing: in vitro effects consistent with lack of in vivo toxicity in human chronic wounds. $\mathrm{Br} \mathrm{J}$ Dermatol. 2002;146 (3):365-74.

15. Lamme EN, Gustafsson TO, Middelkoop E. Cadexomeriodine ointment shows stimulation of epidermal regeneration in experimental full-thickness wounds. Arch Dermatol Res. 1998;290(1-2):18-24.

16. Gilchrist B. Should iodine is reconsidered in wound management? European Tissue Repair Society. J Wound Care. 1997;6(3):148-50.

\section{Correspondence:}

Esther Veronica Brustolin

Rua Mayor Angelo Ferrario Lopes, 211/301

80050-330 Curitiba - PR Brasil

esterbrustolin@gmail.com

Received: July 10, 2012

Review: September 11, 2012

Accepted: October 15, 2012

Conflict of interest: none

Financial source: none

${ }^{1}$ Research performed at Medical Research Institute (IPEM), Postgraduate Program in Principles of Surgery, University Evangelic Hospital of Curitiba, Evangelic Faculty of Parana (FEPAR), Curitiba-PR, Brazil. 